CATALAN REVIEW

Catalan Review

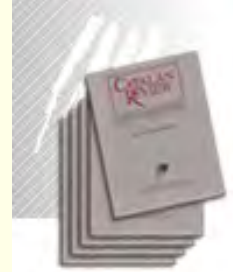

You are accessing the Digital Archive of the Catalan Review Journal.

By accessing and/or using this Digital Archive, you accept and agree to abide by the Terms and Conditions of Use available at http://www.nacs-

catalanstudies.org/catalan review.html

Catalan Review is the premier international scholarly journal devoted to all aspects of Catalan culture. By Catalan culture is understood all manifestations of intellectual and artistic life produced in the Catalan language or in the geographical areas where Catalan is spoken. Catalan Review has been in publication since 1986 .
NORTH

AMERICAN

CATALAN

SOCIETY
Esteu accedint a l'Arxiu Digital del Catalan Review

A l' accedir i / o utilitzar aquest Arxiu Digital, vostè accepta i es compromet a complir els termes i condicions d'ús disponibles a http://www.nacs-

catalanstudies.org/catalan review.html

Catalan Review és la primera revista internacional dedicada a tots els aspectes de la cultura catalana. Per la cultura catalana s'entén totes les manifestacions de la vida intel lectual i artística produïda en llengua catalana o en les zones geogràfiques on es parla català. Catalan Review es publica des de 1986.

\title{
Of Appearance and Disappearance: Theatre and Barcelona (Catalunya invisible, Part II) Sharon G . Feldman
}

Catalan Review, Vol. XVIII, number 1-2, (1998), p. 161-177 


\title{
OF APPEARANCE AND DISAPPEARANCE: THEATRE AND BARCELONA (CATALUNYA INVISIBLE, PART II)*
}

\author{
SHARON G. FELDMAN
}

\begin{abstract}
The relationship between place and stage, and between landscape and theatre, can be enormously revealing in terms of a playwright's sense of self, identity, and culture. During the decades of the 1980 and 1990 , a paradoxical phenomenon occurred whereby the city of Barcelona - or Catalunya, for that matter - as an image, notion, rhetorical figure, or poetic trope seemed to have all but vanished from the contemporary Catalan stage (specifically, from the realm of text-based drama). In the new millennium, however, Barcelona is gradually becoming visible on the stage once again. The three contemporary playwrights examined here - Josep Maria Benet i Jornet, Llüisa Cunillé, and Sergi Belbel - have all displayed an awareness of the aesthetic and political implications of a dialectic of visibility and invisibility, appearance and disappearance.
\end{abstract}

* $\mathrm{E}_{\mathrm{n}}$ algun lloc hem de veure reflectida la nostra imatge d'una manera més rica, més complexa, més contradictòria, més noble, més innoble, més apassionant, més atractiva, en definitive menys avorrida." Such was the point of departure for Catalan director Lluís Pasqual's 1999 précis for the "Ciutat del Teatre," a large-scale urban venture in public theatre, conceived in Barcelona during the late 1990 with contributions from the municipal and provincial governments, the Generalitat de Catalunya, and the Spanish central government. Pasqual, who is, perhaps, the most transnational of Catalan directors, coordinated the project from 1997 to 2000 and calls attention in his précis to the intrinsic relationship between performance and identity, observing the extent to which the theatre continues to preserve its primordial function as a place where societies partake of a complex process of emmirallament, or mirroring, where the members of a given community can reveal themselves to each other and to others.

This essay is, likewise, about the relationship between place and stage and between landscape and theatre in Barcelona, about the ex-

"A segment of this essay appeared in Catalan as "Sobre l'aparició i la desaparició: El teatre i Barcelona, "Pausa 20 (January 2005): 55-66. 
tent to which theatrical space can become a place of collective self-recognition, and about what the portrayal of home and the construction of locality reveal in terms of a playwright's sense of self, identity, and culture. The present is a coda of sorts to a recent essay in which I employed the term Catalunya invisible to describe a phenomenon that had emerged on the post-Franco Catalan stage during the decades of the 1980 s and 1990 . $^{.}$Catalunya invisible refers to a paradoxical situation in which the city of Barcelona - or Catalunya, for that matteras an image, notion, rhetorical figure, or poetic trope seemed to have all but vanished from the contemporary Catalan stage (specifically, from the realm of text-based drama). 1 began to wonder why this had occurred and whether it was possible to read signs of presence in what was seemingly an absence, signs of appearance in what was ostensibly a disappearance. It is a situation that deserves revisiting in light of recent developments, for it appears as though Catalunya, in this new millennium, is gradually becoming visible on the stage once again. Three contemporary playwrights that I shall examine here-Josep Maria Benet i Jornet, Llüisa Cunillé, and Sergi Belbel- have displayed a new awareness of the aesthetic, as well as the political, ramifications that this dialectic of visibility and invisibility brings to the stage.

The erasure of Catalunya that came to define much of contemporary Catalan drama transpired within a remarkably paradoxical context, in that the cultural-or theatrical-politics framing the production of theatre during the post-Franco period were unabatedly preoccupied, even obsessed, with the construction of a triumphant Catalan cultural identity, its international projection, and its protection vis à vis varied manifestations of globalization and Europeanization. During the aforementioned decades, two prominent sites of contention came into the fore: the Teatre Nacional de Catalunya (TNC) and the new Teatre Lliure. Derived from what had been the Centre Dramàtic de la Generalitat de Catalunya, the TNC, situated on the plaça de les Arts (near the plaça de les Glòries), adjacent to the Auditori Nacional de Catalunya, officially opened its doors in 1997 . It is an imposing edifice of pristine stone and glass, a variation on postmodern Greek revival as conceived by architect Ricardo Bofill. It houses three performance spaces, including the 900-seat Sala Gran. The new Lliure, comprising two performance venues, is situated at the opposite end of the city, at the foot of Montjuic, in the rehabilitated noucentista Palau d'Agricultura. Originally designed by Josep Maria Ribas and Manuel M. Mayol for the Barcelona Exposition of 1929, the building was revamped by the architect Manuel Nuñez Yanowski with the collaboration of the late theatre director and

i. See "Catalunya Invisible: Contemporary Theatre in Barcelona." 
scenic designer Fabià Puigserver. It opened its doors in 200I as part of the Ciutat del Teatre project, also comprising the Mercat de les Flors, the Teatre Grec and the Institut del Teatre de la Diputació de Barcelona. Before, during, and after their construction, these architecturally striking and ostensibly lavish public theatre venues became artistic-political battlegrounds, never lacking in their share of melodramatic moments, impassioned accusations, and hysterical outbursts, both on and off the stage.

Yet, while politicians, architects, designers, cultural planners, urban developers, and even theatre directors continually reimagined and envisaged Barcelona's cultural-theatrical landscape, the city, paradoxically, began to take on a nearly invisible, ghostly presence on the contemporary stage. In the private, intimate space of theatrical writing, the dramatists themselves, throughout the decades of the 1980 and I990s, appeared to elude for the most part any sort of cultural specificity. In stark contrast, for example, with their North American counterparts or their contemporaries in Madrid, a substantial cluster of contemporary playwrights, including Carles Batlle, Sergi Belbel, Josep Maria Benet i Jornet, Toni Cabré, Lluïsa Cunillé, Albert Espinosa, Jordi Galceran, David Plana, Josep Pere Peyró, and Mercè Sarrias, began to play with an empty, unmarked spatial territory, setting their plays in indeterminate internal psychic voids or generic urban landscapes. In a move ostensibly towards universalism, as well as, perhaps, a desire for transcendence, a cosmopolitan yearning to project themselves and their work beyond local borders, these Barcelona dramatists virtually erased Barcelona from the stage, turning their backs on the city with a peculiar air of modesty or reticence, as though to name their place of origin or residence would have implied a sinful portrayal of local realism or an overtly gratuitous act of small-minded provincialism. Perhaps, during these post-dictatorial years, the mere gesture of writing or staging a play in the Catalan language served as a sufficiently crucial, o even politically charged, marker of identity. Or, was it that Barcelona's urban landscape - what Julià Guillamon calls an "interrupted city" - was changing so rapidly that it practically escaped concrete representation or description?

It is this geographic loss or sense of displacement - the paradoxical presence of an otherwise absent and invisible Catalunya - that appeared to be a defining trait of contemporary Catalan drama. Indeed Josep Miquel Sobrer has employed the concept of aporia (taken, in spatial terms, as a gap or impasse imbued with doubt or difficulty) to describe a problematic notion of nationhood that appears to permeate modern Catalan literature. I have suggested, in turn, that it might be possible to view cultural identity in contemporary Catalan drama as 
being inscribed not through location, but rather through its avoidance or displacement, that we might view in the lack of spatial geography, or in the evasion of signs of identity, how "Catalanness" is established elliptically or even aporetically, in such a way that its flagrant nonpresence acquires strong connotative powers. ${ }^{2}$ This elliptical or aporetic inscription of identity may constitute a reflection of the ontological and aesthetic implications of our existence within a contemporary culture of shifting borders and transnational crossings and migrations.

There is, for example, an aporetic thrust that drives much of Benet $i$ Jornet's most recent work, as he takes us into mysterious realms and empty voids where we can easily lose our footing and may have difficulty finding our way. With L'babitacio del nen ("The Thirteenth Hour of the Night," 2001), which premiered at the Teatre Lliure de Gràcia during the winter of 2003 under the direction of Belbel (and was awarded the Premi Max 2004 for best Catalan play), he depicted an interior space of ethereal otherworldliness, conjuring in silhouettes and shadows the figure of an anonymous city with apartments containing French doors and balconies; however, he situated much of the action in the space that is designated by the play's aptly enigmatic subtitle, Les tretze de la nit. The "thirteenth hour of the night" signifies a subjective space of spatiotemporal suspension, and in keeping with this context, the play is saturated with references to asteroids, celestial bodies, planets, alien spaceships, far-off galaxies, and black holes, places that serve to shroud in anonymity any concrete references to the city.

As I note in the earlier essay, Benet i Jornet's play Olors ("Smells," 1998) was a curious and glaring exception, perhaps even a turning point, in terms of the pervasive condition of invisibility. ${ }^{3}$ Olors, which premiered in 2000 at the Sala Gran of the TNC, under the direction of Mario Gas, portrayed the urban landscape of Barcelona in the midst of rapid transformation, subtly alluding to the secret-or less visiblelife of the old city and its entrails: the physical demolition of plazas and entire city blocks, and the construction of architectural "marvels," which are the result of the Ajuntament's so-called esponjament (the euphemistic phrase that habitually refers to an "opening up" and gentrification of less prosperous sections of the city). Here, Benet grants Barcelona the role of protagonist and speaks implicitly about the urban transformations and evolving cultural identity of the city. Specifically, he creates a portrait of the interior "patios" of the Raval quarter of his youth.

2. On geopathology, see Una Chaudhuri, Staging Place: The Geography of Modern Drama.

3. The date of composition is given in parenthesis. 
Throughout the past two decades, the Raval, infamously regarded as a haven for prostitutes, thieves, and drug dealers, has witnessed exponential growth in terms of the cultural diversity of its inhabitants, becoming a focal point for the city's new immigrant populations, especially those residents originally from Maghreb, Pakistan, and Latin America. Since the urban renewal projects of the 1980s and 1990s, motivated in part by the Olympic Games of 1992 and the municipal government's social democratic approach to urban development, this area has undergone numerous transformations. Several major cultural institutions, such as the Centre de Cultura Contemporània de Barcelona (1994), the Museu d'Art Contemporàni de Barcelona (1995), and the Foment de les Arts Decoratives (1999), have taken up residence in the Raval, and their physical presence in the vicinity of the Plaça dels Àngels is quite arresting. Increased gentrification and tourism have accompanied the emergence of these cultural focal points within the Raval, and many of the old taverns and bordellos that for decades attracted sailors landing at the port of Barcelona have been replaced with fashionable cafés and galleries. Dilapidated buildings in disrepair have been demolished to pave the way for new apartment blocks and a new tree-lined promenade, the Rambla del Raval, which now traverses the center of the quarter. This striking quantity of construction and reconstruction, coupled with the cultural and economic diversity of the Raval, make this district a site of continual change and displacement, as captured by director José Luis Guerín in his documentary film of the same period En construcción ("In Construction" 20or).

Olors is one of very few contemporary plays from this period to have dared to touch upon the multiethnic realities of the Raval (and, by extension, Barcelona and Catalunya) and its status as a multicultural space. At the beginning of several scenes of the play, Maghrebian music blares in the background, as though it were wafting through the ruins, connoting the presence of a culturally diverse urban population, soon to be displaced. Benet presents in Olors a way of negotiating, through theatrical representation, the literary dilemma underlined by Guillamon, in his cultural analysis $\mathrm{La}$ ciutat interrompuda, of portraying an urban landscape that is in the midst of rapid transformation. For Benet, such a transformation also signifies a disfigurement, or death, of historical memory.

The problem of capturing the passage of time, or of rescuing the neighborhood from disfigurement or extinction, emerges metaphorically in Bener's play through the central character of Maria, who creates, with her photographs, each day at the same exact moment and in the same exact place, a nostalgic portrait of the changing reality of the patios of the Raval. Her snapshots become a metaliterary device within 
the play, for the gesture of taking them replicates the way in which Benet himself portrays reality, as a series of flashes that the spectator must fit together like pieces of a puzzle. It conveys metatheatrically his concern with capturing and making visible on stage the sensation of temporal flux and the subjective urban transformations relative to the perception of each individual moment. The play served (and continues to serve) as a kind of elegy for one of the older, less affluent, marginalized sections of the city as its past is erased or brought tumbling down as a result of economic and political interests. Olor depicts the Raval as it veers toward a state of disappearance, or invisibility, buried beneath the rubble of the wrecking crews.

Barcelona, as I noted in the earlier essay, had managed to resist the absolute vanishing point from the Catalan stage. This near disappearance has not gone unnoticed, nor has the apparent obsession on the part of Catalan dramatists with the limits of cultural specificity. Significantly, Toni Casares, artistic director of the Sala Beckett, one of the city's most innovative venues for experimental drama, attempted to counteract this tendency by focusing upon the theme of Barcelona in preparing the programming for the $2003-04$ season. In a series titled "L'acció té lloc a Barcelona" Casares took the initiative in encouraging both established and up-and-coming dramatists to create a theatrical imaginary grounded in visions of the city. The works commissioned include Vides de tants (Psicopatologia de la vida quotidiana) ("Lives of Many: Psychopathology of Daily Life," 2003) by Albert Mestres; $D o^{\prime} M$ by poet Enric Cassasses; Barcelona, mapa d'ombres ("Barcelona, Map of Shadows," 2004) by Lluisa Cunillé; and Plou a Barcelona ("It's Raining in Barcelona," 2004) by Pau Miró. In addition to these full-fledged productions, Casares commissioned a series titled "Veus de Barcelona," in which he invited several playwrights who have migrated to the city from other areas of the world to create new theatrical portrayals of Barcelona. There was also a marathon of staged readings at the Beckett of fifty-six short theatrical texts titled "Acotació: Barcelona." The entire series earned Casares and the Sala Beckett a prestigious Generalitat de Catalunya Prize in 2005.

Echoing the concerns voiced by Pasqual, Casares outlined his view of the Barcelona stage in a statement regarding the underlying premise of the season's programming:

[E]l teatre ... [é]s un espai de trobada i de mutu reconeixement; un ritual de pactes $i$ complicitats $i$, per tant, ha d'esbandir-se del damunt les pors i els complexes $i$ ha d'oferir-nos als espectadors la possibilitat que ens hi reconeguem. Hem de trobar a l'escenari els nostres llocs, els nostres carrers, els nostres noms, les nostres paraules, les nostres pors, les nostres il-lusions, les nostres circumstàncies.... Volem trobar Barcelona a l'escenari. Mirar-la, redescobrir- 
la, reinventar-la, riure'ns d'ella o plorar-la... Saber parlar de la nostre pròpia ciutat pot voler dir aprendre a comprendre el món. (5-6)

It would seem as though, with Casares's bold programming decision, the fog concealing the Barcelona landscape had finally lifted. There is even a curious hint of collective narcissism that, ironically, seems to color Casares's statement, for his persistent repetition of the first person plural possessive "nostres," common in popular Catalan cultural discourse, appears to take for granted the existence of a coherent collective "we." His comments on the relationship between collective self-reflection/recognition and an understanding of the world beyond the city would indicate, nonetheless, an acknowledgment of a diverse cultural reality.

In her contribution to the series, Barcelona, mapa d'ombres, Cunillé moves from the realm of the "non-place" to that of "someplace," mapping out for the spectator a gendered, eroticized vision of the city of Barcelona, which works against the abstraction that a single collective "we" would imply. 4 Constructed according to the same minimalist aesthetic lines that have come to define Cunillés prolific theatrical trajectory, the play premiered under the direction of Lurdes Barba in March 2004 to resoundingly positive reviews. Marcos Ordóñez succinctly proclaimed on the pages of El País: "no se puede escribir mejor, no se puede interpretar mejor." Indeed Barcelona, mapa d'obres represents a culminating point in Cunillés career, presenting a series of characters whose relationship with urban space plots out a perspective of the city that is inscribed with meaning in terms of power, difference, class, and sexuality.

From beginning to end, throughout the five scenes that comprise the text, Cunillé generates a visual representation of the city, alluding to an urban landscape populated by recognizable (and grandiose) landmarks, which flagrantly engage and codify the play within the context of a discourse on cultural identity that is unmistakably Barcelonan: the Sagrada Família, the plaça de Catalunya, the Gran Teatre del Liceu, the Palau de la Música, the Rambla, the MACBA, and the Estació de França. The play is situated, however, in the more nondescript, less conspicuous, interior space of a pension located in the Eixample district, historically a bastion of the Barcelona bourgeoisie. As Francesc Foguet has observed, the pension serves as a consummate space of transition, occupied by a perpetual flux of transitory beings, "ideal per fer-hi confluir personatges d'orígins,

4. Cf. Marc Augé, Non-Places: Introduction to an Antbropology of Supermodernity.

5. My view of Cunillés representation of the city derives from my reading of Lawrence Knopp, "Sexuality and Urban Space" and Sally Munt, "The Lesbian Flaneur," 
estatus, gustos i sensibilitats." In this sense, Cunillé has, paradoxically, created within the context of a specific, identifiable landscape the type of undifferentiated non-place that we are accustomed to seeing in her theatre.

Beginning with the first scene, and continuing throughout, a recording of Giacomo Puccini's La Bobème, with the Maria Callas in the role of Mimi, plays on the radio in the background, immediately lending an air of decadence and unconventionality to the play. The elderly male owner of the pension is revealed to be terminally ill with cancer. On a summer night, he and his wife, "Ell" and "Ella," who are hoping to spend their remaining days together in peace and tranquility, ask the boarders of the pension to vacate their rooms, one by one. Through their dialogues, always in pairs, these placeless beings, surprising in their intermingling of ordinariness and eccentricity, disclose fragments and recall scenes from their lives, while, through their narratives, the monumental landscape of the city unfolds. She is from a working-class family, and when she hears voices in the middle of the night, she sings a piece of opera. She once had a daughter, who was killed when she was hit by a bus on the Passeig de Gràcia (32). He used to live in the working-class, seafront district known as Poble Nou. His father, one can derive from the conversation, was a construction worker who emigrated to Catalunya from Murcia,

Among the tenants is a woman ("Dona"), who earns a modest living teaching French classes. She once lived near a cemetery (very likely, that of Poble Nou) and migrated to the Raval when construction began on the Vila Olímpica (transforming a modest section of Poble Nou, first into housing for the athletes of the Olympic Games of 1992 and then into modern apartment blocks for the upwardly-mobile middle class). She mentions that she has written a novel. Her son is an architect, specializing in the absurd métier of designing xamfrans, the chamfered corners that are a distinguishing feature of the intersections of the Eixample. The woman has a penchant for wandering about the city at night, rather then during the light of day: "Alguna nit m'aturo davant les finestres on hi ha llum i la persiana aixecada, i observo una estona la gent que hi viu a dins" (13). Her wanderings, in which she stops to observe the spectacle of illuminated windows, are reminiscent of those described by Benjamin in his writings (d'après Charles Baudelaire) on the figure of the Parisian flaneur, who strolls unhurriedly throughout the urban streets, never quite incorporating himself into the crowd, delighting voyeuristically in the everyday, and contemplating the urban scene with the detached, even melancholic, eye of a painter-or what Baudelaire referred to as a "passionate spectator" (9). 
In a conversation with the pension owner, the woman explains that, when her son was a child, he would often accompany her on her urban wanderings:

Des de molt petit ja el portava a passejar amb mi per Barcelona, aleshores m'agradava retratar fàbriques abandonades i solars buits. Qui sap si per aquesta raó ara li fan panic els espais amples i buits com a tots els mals arquitectes. L'única cosa en la qual estem d'acord tots dos des de sempre és que cada vegada que passem per davant de la Sagrada Família ens vénen ganes de cridar... He passat temporades llargues a fora, però sempre hi torno. I ara ja res m'estalviarà la transformació final, aquella que farà definitivament de Barcelona una ciutat intercanviable amb qualsevol altra capital occidental benestant i autosatisfeta. (17)

Entwined with the woman's discourse is what appears to be a metatheatrical reflection on the part of Cunillé, who, like the woman, once displayed an affinity for portraying abandoned factories and empty lots, and now has opted to offer a view of an urban terrain grounded in spatial particularities. The woman's commentary refers, moreover, to the contemporary transformations that rapidly have altered the face of the Barcelona urban landscape, which, in her opinion, have caused it to lose a certain individuality. Europeaness is thus equated with a loss of cultural identity.

Scene 3 presents the third and final boarder, a young, pregnant, Spanish-speaking immigrant who works at a restaurant. She is generically referred to in the text as "Estrangera," and in her conversation with the pension owner, she divulges the surprising news that he is the father of her child. He, in turn, is revealed to have an affinity for crossdressing, a practice that he began cultivating several years earlier when, as an employee of the Liceu opera house, he developed a habit of secretly trying on feminine costumes backstage (43). His wife has also engaged in the practice of cross-dressing with the idea that, eventually, disguised as her husband, she might be able to sign for his pension after he has passed away.

In the fifth and final scene of the play, there is a revealing moment in which the pension owner explains to his wife that, prior to his work at the Liceu, he was employed as a kind of urban cartographer, having assisted in the production of a Barcelona guidebook, filled with maps of the city. He gives his wife one of the guidebooks in which he has made a series of numerical markings indicating the hours of the day at which each street is left shaded by the movement of the sun. "És com un gran mapa d'ombres," she tells him (6I). This map of shadows, in a metatextual sense, plots an intriguing visual rendition of Cunillés conception of the city. In a manner that is vaguely reminiscent of Benjamin's utopian descriptions of the Parisian arcades, 
the preferred domain of flânerie, Cunillé fashions Barcelona into a place in which the edgy, excessive, eccentric, heterogeneous area of the Rambla and the Liceu, a part of the city known for its multiple offerings of public spectacle, has crossed over and intermingled with the private, staid, homogeneous realm of urban bourgeois domesticity that is the Eixample. Markers of identity-sexual, cultural, social, and otherwise-are no longer black and white, but rather, shaded by the shadows that are conjured by the movement of the sun.

In this map of shadows, Cunillê has found a way to work against social and cultural hierarchies as they materialize upon the map of the city, offering an alternative gaze that underscores creativity and imagination. In the portrayal of the cross-dressing couple, as well a procession of characters whose identities that are far from fixed, she has contemplated the urban landscape through a lens of constantly shifting subjectivities, consequently undoing social and cultural codings of high and the low, masculine and feminine, center and margin-codings that, historically have been superimposed upon conventional representations of the geography of the city. Sally Munt has theorized with regard to the existence of a "lesbian flaneur," whose "imagination is freed from cultural constraints to wander at will," (II7). Cunillé's characters, likewise, offer a view of Barcelona that undermines heteropatriarchal definitions, transporting us to those mysterious, marginal, concealed spaces that exist in the realm of the urban everyday, where identity is always elusive and enigmatic.

The spatial terrain of Catalan culture is a symbolic landscape of emotion, perception, and subjectivity. Barcelona, likewise, has emerged and reemerged throughout the present century and the last as a transcultural space of migration. In a city in which, at present, at least fourteen percent of the population is from beyond Spanish borders (with a large portion of Moslem origin), it seems as though Catalan dramatists are now poised to take into account the space of cultural pluralism that they know as "home." The process of selfrecognition and self-conscious desire in the theatre is, indeed, a complex one. Speaking about what he called the "privileged" places of his own theatre, the late French playwright and visionary BernardMarie Koltès once commented that his play Combat de nègre et de chiens ("Black Battles with Dogs"), which is situated in West Africa, is not really about Africa and "Blacks" but is, in effect, about France and "Whites" (30-3i). Just as Koltès held up a mirror to the French unconscious, exposing the painful consequences of a racist past that many may not want to see, Catalan dramatists are perhaps ready to

ซ. See Ramon Suñé regarding Barcelona immigration statistics. 
confront conscious and unconscious (invisible) fears imbedded in their own collective memory.

Sergi Belbel (who is a great admirer of Koltès, having staged and translated several of his plays) ponders issues of cultural and ethnic diversity, displacement and migration, racism and ethnocentricity, assimilation and integration in his recent play Forasters ("Strangers," 2003). Having premiered under his own direction at the Sala Petita of the TNC in September 2004, Forasters is probably Belbel's most ambitious work to date and was commissioned in conjunction with the rather polemical "Fòrum Universal de les Cultures Barcelona2004." It is the saga of a European family whose pain and trauma, both physical and existential, emerge as part of a foreboding cycle of repetition. Through a curious play of temporal and spatial intersections, parallelisms, and collisions, this two-part melodrama (framed by a prologue and epilogue) appears to manifest an awareness on the part of Belbel that performance, in essence, hinges upon a tenuous rapport between the living and the dead. Joseph Roach correspondingly reminds us that the creation of a theatre spectacle is a process of substitution or "surrogation" through which we resuscitate or reincarnate past lives. For Roach, performance is therefore inextricably entangled with the notions of history, memory, and repetition. It enables us "to preserve a sense of the relationship with the past by making physical contact with the dead" ("History, Memory, Necrophilia" 29).7 Forasters, likewise, proposes a relationship between memory and the theatre spectacle that is grounded in strategies of substitution; that is, through the employment of an array of characters who appear before the audience as specters of the past.

Belbel's play, which is subtitled Melodrama familiar en dos temps ("Family Melodrama in Two Periods"), is situated in the twentieth century (specifically, the decade of the 1960s) and the present-day twenty-first century. The scenic space is a large urban apartment occupied by several generations of the same bourgeois European family over the course of the two centuries. The action shifts and alternates seamlessly between the two periods, and while the physical space remains stagnant, Belbel proposes in his opening description that lighting techniques be used to demarcate the temporal distinctions: "Ara bé, els canvis han de ser instantanis. Encara que és la llum, dèbil i groguenca als anys 6o, blanca i més potent al segle XXI, el que millor diferencia els dos moments dels temps" (29).

Notwithstanding the lighting design, the stage directions indicate that a sense of confusion between the two time periods is desirable 
and even encouraged. In typical Belbelian fashion, the text proposes an intriguing casting strategy that produces a kind of temporal trepidation, entailing effects of doubling, repetition, and simultaneity, as the two centuries appear to intermingle and intersect. According to the proposed scheme, the actor who portrays the grandfather during the twentieth century is also the father in the twenty-first, the mother during the twentieth century is the daughter in the twenty-first, and so on. Belbel's casting strategy is intended to yield unanticipated visual effects, whereby many of the characters in the play appear to "evolve" in adulthood into duplicate images of their parents. For the production at the TNC, scenic designers Estel Cristià and Max Glaenzel employed a mobile proscenium stage, which rotated approximately ninety degrees with each alternating shift in time. ${ }^{8}$ During some of the most visually captivating moments, the audience was able to witness the image of the stage revolving as the characters crossed a threshold and appeared magically to undergo a transformation into a previous or future incarnation. With this effect of theatrical ghosting, the faces of the characters were blurred and confused in a crisis of discinctions that visually accentuated the notions of repetition and memory. Time progressed, and yet it also appeared to stand still.

Situated at the center of each generation, as the axis around which all events revolve, is a woman (the mother in the twentieth century, the daughter in the twenty-first), who is terminally ill with cancer. The mother/daughter, who describes herself as podrida (or, in a constant state of decay), contemplates from the vantage point of her deathbed (through the doorway of the bedroom, which is often left open) her past, the lives of previous generations, and the endless cycle of pain that seems to traverse not only her body, but also her relationships with others.

Although Belbel does not name Barcelona explicitly in the text (and, for that matter, has never named this city in any of his plays), there are several aspects of the context that are distinctly reminiscent of the multicultural and multiethnic conditions that have underpinned the evolution of the city, as well as Catalunya, Spain, and Europe. Whereas during the post-civil war years, Catalunya, with its ever-increasing industrialization and economic prosperity, became a prominent focal point for large waves of migration from economically underdeveloped areas of Spain, during the post-Franco years (especially the rg9os and the present decade), it became a popular destination for thousands of immigrants from other continents, especially Africa and Latin America. Thus, to be a foraster - a "stranger" or

8. I draw upon my own experience as a spectator in describing the production of Forasters at the TNC. 
"foreigner" - in Barcelona during the decades depicted here carries multiple connotations. Belbel's play takes full advantage of the ambiguous, polysemous value of the title, Forasters, transferring metonymically all the meanings that the term connotes to the spatial geography of the apartment building in which the action takes place.

In the most literal, concrete sense, forasters refers to the family living upstairs, in the invisible space that is the apartment situated directly above the one that is depicted on stage. The twentiethcentury inhabitants of this upstairs apartment are characterized as immigrants from another culture, seemingly underprivileged, unassimilated, subaltern subjects whose presence poses a series of cultural, ethnic, and/or racial points of contrast with the members of the bourgeois European family living downstairs. In the twenty-first century, the cultural gap between these different worlds is even more pronounced, for the upstairs neighbors are described as being émigrés not only from another culture, but also from another continent. The upstairs apartment is never revealed to the spectator; yet, the space is evoked in acoustic terms and referenced through several derogatory cultural clichés often associated with immigrant populations. In a manner reminiscent of the Maghrebian music of Benet's Olors, loud non-Western music emanates from the space above, along with the sonorous movement of furniture (the implication being that several people are living in a relatively small space). The bellowing of voices is heard (the husband, who lives upstairs is physically abusive in his treatment of his wife). In spite of the clichés, and, perhaps, in a conscious move to unravel, critique, or deconstruct them, Belbel's plot creates an upstairs/downstairs dialectic in which the two worlds collide and then intermingle and overlap within the same urban building.

This unraveling and collision occurs in the sense that Belbel does not confine the meaning of foraster to the foregoing literal interpretations; he manipulates the notion of "stranger" or "foreigner" in an existential - even Camusian - sense, creating a degree of uncertainty with regard to whether it is the immigrant family living upstairs or the assimilated family downstairs who are indeed "strangers" in this world.? The boundaries distinguishing the two apartments/two worlds, upstairs/downstairs, invisible/visible, become increasingly porous as the action begins to undermine the traditional, staid, culturally homogeneous bourgeois space of melodrama (and, by extension, of Catalan cultural politics) and gives way to signs of cultural hybridity and an increasingly anti-realist aesthetic. The romantic union in the

9. It is perhaps not entirely an accident, then, that the title of the play would be evocative of Albert Camus's L'étranger (1946). In fact, in an early draft of the text, Belbel titled the play Estrangers. 
twentieth century between the daughter from downstairs and the male neighbor from upstairs (a union that is duplicated in the twenty-firstcentury relationship between the granddaughter and the young man) suggests a situation of cultural mestissatge that serves to thwart even further the distinctions between the two worlds.

Given the parallels that Belbel tends to establish between plot and structure, it is possible to read an analogous replication of these crosscultural relationships and cultural-ethnic-racial ambiguities in the temporal ambiguity of the play. It is in this lack of distinctions, and in this trepidation and uncertainty, that one finds the expressive power of the Forasters, for just as the two "worlds" collide, so do the two temporal planes. Near the end of the play, there is a magical moment in which the twentieth-first-century daughter, who is on the verge of death, looks beyond her bedroom threshold to contemplate the image of her granddaughter. In so doing, she also is able to see, simultaneously, an earlier incarnation of herself (since the same actress who plays the role of the granddaughter is also the daughter in the twentieth century). The women's gazes meet and multiply as they become endowed with a seemingly supernatural capacity to traverse centuries. Belbel's stage directions read as follows:

Els ulls oberts de la mare-filla semblen clavar-se bruscament en els de la fillanêta.

La mirada que va de l'una a l'altra, inesperadament, sembla materialitzar-se, fora del temps i l'espai. Un raig de llum imperceptible uneix màgicament uns ulls amb els altres.

La mare morta mira la seva filla, al segle xx; i la filla mira la seva mare...

La filla morta mira la seva neboda, al segle xxI; i la neboda mira la seva tieta... Però també...

La mare morta, al segle Xx, veu la seva néta al segle XxI; i la néta veu l'àvia que no va conèixer...

I, encara més...

La filla morta al segle XXI es mira a ella mateixa quaranta anys enrere, es retroba amb ella en el moment més decisiu de la seva vida; i la filla al segle XX es veu a ella mateixa i mira la seva pròpia mort, al mateix lloc que la mare, quaranta anys més tard.

...I, aleshores, totes elles semblen entendre un misteri fins aleshores ocult o impenetrable.

Inmediatament, el dèbil resplendor que uneix els ulls i materialitza les mirades $s^{\prime}$ intensifica bruscament fins a tal punt que envaeix tot l'espai en dècimes de segon i acaba esclatant amb una brutal explosió d'una lluminositat absolutament cegadora.

Com si assistíssim, de cop, a l'origen de l'univers.

I sobtadament, fosc. $(147-48)$ 
For Belbel's production of Forasters at the TNC, Cristià and Glaenzel employed a series of mirrors in order to create the sort of visual mise en abyme that is evoked here. As the characters from the twenty-first century confront the ghosts from the past, the past lives are also able to gaze into the "furure." The boundaries of time are swept away, and the characters are transformed into ethereal beings that appear to levitate, their identities vacillating in an atemporal anyplace, climaxing in a grand-scale explosion that is evocative of the origin of the universe. There is thus an aura of inevitability that pervades the play, as though there were a secret, elusive pattern at work, and as though the characters were somehow fatalistically condemned to relive the lives of their predecessors. Perhaps this is the mystery of which Belbel speaks in his vivid stage directions, for in Forasters, memory, is established not only in an individual sense, but also in a collective sense: the historical memory of an entire people. It asks us to contemplate the present in relation to the past and to recall the fluid nature of Catalan cultural identity.

Belbel emphasizes this lack of distinctions with the revelation that a neighbor from upstairs has purchased the downstairs apartment (a revelation that emerges in the prologue as an element of foreshadowing and culminates in the epilogue, thereby forming a frame that encases the remainder of the dramatic action). Having once belonged to the invisible upstairs realm, the neighbor's appropriation of the downstairs space sets in motion a series of ethno-national connotations with regard to the migratory space that is Barcelona, Catalunya, Spain, or Europe. What was once a space of invisibility will now become visible.

Belbel, who is at the forefront of his theatrical generation, is accustomed to playing on a global stage; yet, curiously, this is the first play that he has written that addresses - albeit, without naming names - the cultural realities of his own city. Along with Benet and Cunillé, he appears to have begun to overcome the prevalent air of anxiety and hesitation with regard exhibiting an interest in localism and locality. All three playwrights have moved beyond the shadows and silhouettes of an unmarked urban territory, demonstrating an awareness of the shifting sociocultural terrain that comprises the contemporary Barcelona landscape. These texts are, indeed, likely to cross borders one day - as the works of Benet, Cunille, and Belbel often do- and when they play in Paris, Copenhagen, Buenos Aires, or New York, the specter of Barcelona will be recognizable, its appearance more complex and contradictory than, perhaps, ever before. 


\section{WORKS CITED}

AugÉ, Marc. Non-Places: Introduction to an Anthropology of Supermodernity. Trans. John Howe. New York: Verso, 1995.

BaudelaIRE, Charles. The Painter of Modern Life and Other Essays. New York and London: $\mathrm{Da}$ Capo, 1986.

Belbel, Sergi. Forasters, Preface Josep M. Benet i Jornet and Sharon G. Feldman. Barcelona: Proa/Teatre Nacional de Catalunya, 2004.

Bell, David and Gill VALENTINe. Mapping Desire: Geographies of Sexualities. London: Routledge, 1995.

BENET I JORNET, Josep M. L'babitació del nen (Les tretze de la nit). Barcelona: Edicions 62, 2003.

_- Olors. Preface Josep M, Benet i Jornet and Enric Gallén. Barcelona: Proa/Teatre Nacional de Catalunya, 2000.

Benjamin, Walter. The Arcades Project. Trans. Howard Eiland and Kevin McLaughlin. Cambridge: Harvard UP, 2002.

CASARES, Toni. "A Barcelona: Una temporada de teatre local a la Sala Beckett." Preface. En cartell: Sèrie "A Barcelona." Barcelona: RE \& $\mathrm{MA}_{12} / \mathrm{L}^{\prime} \mathrm{O}$ brador de la Sala Beckett, 2004. 5-6

ChaudHURI, Una. Staging Place: The Geography of Modern Drama. Ann Arbor: U of Michigan P, 1995 .

Cunillé, Llüisa. Barcelona, mapa d'ombres. En cartell: Sèrie "A Barcelona." Barcelona: RE\&MA i2 / L'Obrador de la Sala Beckett, 2004. 7-66.

En construcción. Screenplay by José Luis Guerín. Dir. Josê Luis Guerín, 200 I

FeldMAN, Sharon G. "Catalunya Invisible: Contemporary Theatre in Barcelona." Special Cluster: "Barcelona." Ed. Brad Epps. Arizona Journal of Hispanic Cultural Studies 6 (2002): 269-87.

FOGUET, Francesc. "Barcelona, mapa d'ombres." En cartell: Sèrie "A Barcelona." Barcelona: RE\&MA I2 / L'Obrador de la Sala Beckett, 2004. N.p.

GUIL LAMON, Julià. La cintat interrompuda. Barcelona: La Magrana, 200I. KNOPP, Lawrence. "Sexuality and Urban Space: A Framework for Analysis." Bell and Valentine, 149-61.

KoLTĖs, Bernard-Marie. "Des lieux privilégiés." Europe 823-24 (Nov.Dec, 1997): 30-31.

MUNT, Sally. "The Lesbian Flâneur," Bell and Valentine. II4-25.

ORDÓNEZ, Marcos. "Barcelona, mapa de sombras": caza mayor. El Pais (Babelia) March 2004.

PASQUal, Lluís. Projecte Cintat del Teatre, 1999. <http://www. ciutateatre.com>.

PuCcini, Giacomo. La Bohème. Libretto by Luigi Illica and Giuseppe Giacosa. 1896. 
ROACH, Joseph. Cities of the Dead: Circum-Atlantic Performance. New York: Columbia UP, 1996.

- "History, Memory, Necrophilia." The Ends of Performance. Ed. Peggy Phelan and Jill Lane. New York: New York UP, 1997: 23-30.

SOBRER, Josep-Miquel. "The Moving Mountain: Aporias of Nineteenth-Century Catalan Ideology." Catalan Review I4.1-2 (2000): 173-88.

SUNEE, Ramon. "Crecimiento sostenido," La Vanguardia Digital. 3 December 2005. 